\title{
A responsabilização no pagamento de créditos trabalhistas diante da insolvência econômica e patrimonial
}

O inadimplemento dos créditos trabalhistas por parte do empregador é tema de ampla divergência perante os tribunais e da própria doutrina, buscando-se amparo e segurança jurídica na lei. O tema é de crucial relevância, visto que permite, de forma muito mais abrangente e contumaz a satisfação do crédito, que por vias ordinárias não veio a ser adimplido. Portanto, tem por objetivo analisar as possibilidades cabíveis para facilitar o adimplemento e impedir o inadimplemento de obrigações trabalhistas, diante das inúmeras situações em que o trabalhador se vê impossibilitado de executar o seu título. Visa analisar as possibilidades de responsabilização, caracterizando-as e diferenciando-as de acordo com a doutrina e jurisprudência para que se possa compreender as dificuldades encontradas na execução do título em face do executado com insuficiência econômica e patrimonial, a partir de uma seleção de bibliografia e documentos afins à temática e em meios físicos e na Internet.

Palavras-chave: Débitos trabalhistas; Processo do Trabalho; Modalidades de execução.

\section{The responsibility in the payment of labor credits in the face of economic and equity insolvency}

\begin{abstract}
The default of labor claims by the employer is a subject of wide divergence before the courts and from the doctrine itself, seeking legal protection and legal certainty. The topic is of crucial relevance, since it allows, in a much more comprehensive and recurrent way, credit satisfaction, which by ordinary means has not been fulfilled. Therefore, it aims to analyze the possible possibilities to facilitate the performance and prevent the default of labor obligations, in view of the numerous situations in which the worker is unable to execute his title. It aims to analyze the possibilities of accountability, characterizing and differentiating them according to the doctrine and jurisprudence so that one can understand the difficulties encountered in the execution of the title in the face of those executed with economic and patrimonial insufficiency, based on a selection of bibliography and documents related to the theme and in physical media and on the Internet.
\end{abstract}

Keywords: Labor debts; Work Process; Implementation modalities.

Topic: Direito do Trabalho e Processo do Trabalho

Reviewed anonymously in the process of blind peer.

Vanessa Caroline Cardoso

Universidade Regional do Noroeste do Estado do Rio Grande do Sul, Brasil http://lattes.cnpq.br/0899046368343300

http://orcid.org/0000-0001-9814-5280

vanessa.c.cardoso21@gmail.com
Received: 20/05/2020

Approved: 18/08/2020
Referencing this:

CARDOSO, V. C.. A responsabilização no pagamento de créditos trabalhistas diante da insolvência econômica e patrimonial. Scientiam Juris, v.8, n.2, p.14-31, 2020. DOI: http://doi.org/10.6008/CBPC23183039.2020.002.0002 


\section{INTRODUÇÃO}

Muitas vezes, mesmo após terem percorrido o trajeto processual em busca da cognição de seu direito até a formação do título executivo judicial, ou mesmo sendo possuidor de um título executivo extrajudicial, o credor acaba não obtendo satisfeita a obrigação. Esses e outros casos fragilizam os direitos previstos na CLT, Constituição Federal e demais dispositivos normativos, podendo ensejar grande insegurança jurídica, econômica e social.

Nesse diapasão, o presente trabalho apresenta um estudo direcionado à análise dos institutos cabíveis acerca das ferramentas processuais a serem utilizadas para o resguardo do direito à efetividade do cumprimento da sentença judicial que defere créditos trabalhistas. Sendo assim, vislumbra-se destacar o enfoque do presente trabalho, qual seja, a execução em face de um devedor insolvente.

Nesse diapasão, o estudo abordado permite, de forma abrangente e contumaz a compreensão acerca da importância da satisfação do crédito, que por vias ordinárias não veio a ser adimplido. Portanto, cria mecanismos para que as práticas de exoneração de patrimônio, criação de empresas fantasmas, formação de vínculos trabalhistas não registrados, entre outros casos, possam ser mais pacificamente solucionados, para que o trabalhador não se logre prejudicado.

Visto isso, é inaceitável que o inadimplemento seja admissível e menos ainda que tal prática tornese recorrente. É dever do empregador assumir o ônus e as variáveis decorrentes de sua atividade. Mais do que isso, a ele incumbe atender aos direitos e deveres para com os colaboradores de seu empreendimento, devendo ser resguardada a aplicabilidade de seus direitos, que demoraram séculos para consolidarem-se.

Ocorre que, na prática, o descumprimento contratual por parte do empregador e, consequentemente, inexecução dos créditos trabalhistas revelam-se prática progressivamente recorrente. É nesse contexto que se enquadram as modalidades de execução presentes em nosso ordenamento jurídico, que se constituem em importantes ferramentas disponíveis ao credor de alimentos.

\section{DISCUSSÃO TEÓRICA}

\section{Execução em face de Devedor Insolvente}

A execução em geral está amparada no Código de Processo Civil - CPC, que disciplina os dois tipos de execução existentes no ordenamento jurídico atualmente. Fundamenta, portanto, as diferenças cruciais existentes entre a execução fundada em título judicial, tratada como cumprimento de sentença, e a fundada em título executivo extrajudicial.

Entretanto, diante das previsões normativas e interpretações judiciais a respeito do tema, faz-se necessário o entendimento da execução em face de devedor insolvente. Para isso, inicialmente, é fundamental a conceituação sobre o estado de insolvência, as suas características e requisitos, a sua diferenciação da falência, e a sua definição em lei.

A insolvência patrimonial trata-se de um estado de insuficiência patrimonial apresentado pelo devedor sobre uma dívida, ou seja, os bens que o devedor possui tornam-se insuficientes para cobrir o 
montante constituído pelas obrigações contraídas. Sobre o assunto, elenca Gomes (2013):

A insolvência civil equivale à falência de quem não é empresário, ou seja, é a situação da pessoa física que possui mais dívidas do que poder econômico para saldá-las, da pessoa que tenha um passivo maior do que o ativo, o que gera uma insegurança jurídica.

Nesse sentido, o artigo 748 do antigo Código de Processo Civil conceitua como insolvência a situação em que as dívidas excedem à importância dos bens do devedor. Ou seja, trata da insuficiência patrimonial daquele devedor que não se enquadra ao conceito de empresário ou que não pertença a uma empresa.

Além disso, o antigo código definia como requisitos objetivos as previsões dos seus artigos 750 e 813 . Assim, destacam-se como tais requisitos o fato de o devedor não possuir outros bens para nomear à penhora; arresto sobre bens do devedor sem domicílio certo, que intenta ausentar-se e alienar os bens que possui, ou deixa de adimplir obrigações no tempo estipulado.

Ademais, enquadra-se também qualquer ato que vise frustrar a execução de terceiros, utilizando-se de meios fraudulentos como tentativa de ausentar-se; alienar bens; contrair dívidas, transpassar seus bens à terceiros, hipotecá-los a fim de ficar sem nenhum deles livre e desembargado que possa cobrir às dívidas. Nesse diapasão, difere-se a insolvência civil da falência, visto que a insolvência se constitui como atributo possível somente às pessoas físicas que não se enquadrarem como empresários, enquanto que a falência poderá ser decretada por pessoas jurídicas de direito privado. Em relação ao tema, explana Coelho (2011):

Para fins de instauração da execução por falência, a insolvência não se caracteriza por um determinado estado patrimonial, mas sim pela ocorrência de um dos fatos previstos em lei. Em outros termos, a insolvência se caracteriza, para o direito falimentar, quando o empresário for injustificadamente impontual no cumprimento de obrigação liquida (LF, art.94, I), incorrer em execução frustrada (art. 94, II) ou praticar ato de falência (art. 94, III). Se restar caracterizada a impontualidade injustificada, a execução frustrada ou o ato de falência, mesmo que o empresário tenha seu ativo superior ao passivo, será decretada a falência; ao revés, se não ficar demonstrada nenhuma destas hipóteses, não será instaurada a falência ainda que o passivo do devedor seja superior ao ativo. A insolvência que a lei considera pressuposto para execução por falência é meramente presumida.

Perante créditos trabalhistas ambos os institutos são possíveis, pois poderá também o trabalhador desempenhar atividades para um empregador que não se enquadre como empresa, tais como o empregador doméstico. Portanto, é importante compreender que a conceituação orientada acima serve para melhor se compreender o que significa de fato a insolvência e de que forma isso pode prejudicar o credor de obrigações trabalhistas.

Assim sendo, o trabalhador que percebe as suas obrigações não satisfeitas e que resolve socorrer-se no judiciário, e já na fase de execução, após a inadimplência do empregador, verifica a inexistência de bens, deve conhecer os caminhos possíveis para buscar valer-se de seu direito.

Em razão de uma certa frequência e aumento do número de casos em que o credor de créditos trabalhistas se viu prejudicado em situações semelhantes à descrita acima, a Consolidação das Leis do Trabalho já previu alguns mecanismos possíveis para impedir novos acontecimentos, tais como, a arguição de falência, a responsabilidade subsidiária, a solidária e a desconsideração da personalidade jurídica. Tais institutos serão elencados nos próximos itens 


\section{A arguição de Falência}

Considerando as ressalvas acima a respeito da insolvência patrimonial, para que se possa utilizar do instituto da falência, se faz necessária a obediência a alguns requisitos. O primeiro deles, de fundamental importância, corresponde à necessidade de que a execução esteja fundada em face de uma sociedade empresária ou de um empresário individual, com atenção aos requisitos de existência para cada uma delas. Nesse sentido, Coelho (2011):

Sempre que o devedor é legalmente empresário, a execução concursal de seu patrimônio faz-se pela falência. Em outros termos, quando o devedor explora sua atividade econômica de forma empresarial - caracterizada pela conjugação dos fatores de produção: investimento de capital, contratação de mão de obra, aquisição de insumos, desenvolvimento ou compra de tecnologia -, não sendo capaz de honrar suas obrigações no vencimento (ou estando presentes outros fatos tipificados em lei), o juiz deve inaugurar um procedimento de execução concursal destinado à satisfação dos credores, no quanto for possível. Este procedimento é a falência.

Ademais, conforme Coelho (2011) conceitua que estão sujeitos ao instituto da falência os profissionais que se enquadram na conceituação prevista no artigo 966 do Código Civil, os legalmente empresários. O conceito abrange aqueles que pratiquem as mais variadas atividades, como a comercial, prestadoras de serviços, construtoras e imobiliárias, excluindo apenas os profissionais liberais, artistas e o explorador de atividade rural, quando não cadastrado no Registro de Empresas.

Assim, para fins da instauração da falência, outro requisito necessário é a insuficiência patrimonial por parte da empresa. Ou seja, a presente modalidade pressupõe que seja declarada a insolvência, jurídica ou presumida, do devedor. Tal situação ocorrerá nos casos previstos no artigo 94 da Lei de Falências - LF e seus incisos, que disciplina comportamentos ou práticas tendenciosas à utilização do instituto.

Segundo Coelho (2011), para ser figurada a insuficiência, a prova da existência de um ativo superior ao passivo é insignificante, já que o estado de fato não caracteriza uma empresa como solvente. Portanto, é importante que se caracterize um dos fatos previstos em lei, assim sendo se o devedor for injustificadamente impontual no cumprimento de uma obrigação (LF, art. 94, I), incorrer em uma execução frustrada (LF, art. 94, II) ou se praticar algum ato de falência (LF, 94, III).

É importante ressaltar, ainda, que quando o Decreto-lei 7.661/1945 foi substituído pela lei em destaque, surgiu uma nova preocupação, a de não permitir que o processo inaugural da declaração de falência tenha por objetivo a cobrança de uma dívida. Tal preocupação veio para cessar essa prática que já era recorrente, e assim permitir certa tranquilidade para os empresários. Assim explana Ramos (2015):

A severidade do sistema da impontualidade, já apontada, fez com que a ação de falência fosse utilizada, diversas vezes, como mero instrumento de cobrança de dívidas não pagas. Como a legislação falimentar anterior era muito severa, o devedor empresário que era citado em um processo falimentar ficava muitas vezes desesperado, optando por pagar a dívida ou depositar o seu valor para elidir a sua falência, ainda que para ele essa dívida, eventualmente, pudesse ser contestada.

Coelho (2011) ainda assevera que sobre a impontualidade referida, é necessário que se trate sobre uma obrigação líquida, caracterizada como tal quando for apresentada por um título executivo, podendo ser ele judicial ou extrajudicial. No entanto, algumas obrigações, mesmo sendo líquidas, são excluídas da 
impontualidade de que se trata a Lei de Falências, como as obrigações gratuitas, prevista no artigo $5^{\circ}$ da referida lei.

Ademais, sobre a impontualidade injustificada, a própria lei sugere em seu artigo 96, que nos casos em que não houver a justificação, ou seja, uma relevante motivação para o não pagamento restará configurada a impontualidade injustificada. Portanto, as causas listadas no artigo supracitado justificam a impontualidade e eliminam a caracterização da decretação de falência. Assim prescreve o artigo:

Art. 96. A falência requerida com base no art. 94, inciso I do caput, desta Lei, não será decretada se o requerido provar:

I - Falsidade de título;

II - Prescrição;

III - Nulidade de obrigação ou de título;

IV - Pagamento da dívida;

V - Qualquer outro fato que extinga ou suspenda obrigação ou não legitime a cobrança de título;

$\mathrm{VI}$ - Vício em protesto ou em seu instrumento;

VII - Apresentação de pedido de recuperação judicial no prazo da contestação, observados os requisitos do art. 51 desta Lei;

VIII - Cessação das atividades empresariais mais de 2 (dois) anos antes do pedido de falência, comprovada por documento hábil do Registro Público de Empresas, o qual não prevalecerá contraprova de exercício posterior ao ato registrado.

$\S 1$ 으o Não será decretada a falência de sociedade anônima após liquidado e partilhado seu ativo nem do espólio após 1 (um) ano da morte do devedor.

$\S 2$ - As defesas previstas nos incisos I a VI do caput deste artigo não obstam a decretação de falência se, ao final, restarem obrigações não atingidas pelas defesas em montante que supere o limite previsto naquele dispositivo. (BRASIL, 2005)

Outrossim, mesmo que se tratem de obrigações líquidas a referida injustificação não se trata de um fim em si mesmo, ou seja, para que se configure a falência embasada nesse fim os títulos elencados devem atingir o limite mínimo de 40 salários mínimos. Assim destaca o artigo 94 da Lei em destaque, permitindo, ainda o litisconsórcio entre credores de um mesmo empresário, a fim de atingir a soma necessária. Assim ressalta Coelho (2011):

Em suma, para que se encontre tipificado o comportamento descrito pelo art. 94, I, da LF, e, portanto, seja possível a instauração da execução concursal por falência, é necessário que o devedor empresário tenha sido impontual, sem relevante razão jurídica, no cumprimento de uma obrigação documentada em título executivo de valor superior a 40 salários mínimos. Dita impontualidade, outrossim, deverá ser provada, necessariamente, pelo protesto, cambial ou especial, do título correspondente.

Em complementação ao que se refere o artigo, a própria lei, em seu parágrafo 3ำ do artigo 94, determina que como instrumento para demonstrar a impontualidade, o protesto se constitui em um meio de prova. Sendo assim, dentro das limitações da lei, é importante que o credor, antes mesmo de ajuizar a ação de falência, proteste o título, para demonstrar nos autos que houve a tentativa de cobrança do título extrajudicial.

Assim ressalta Ramos (2015):

Portanto, fica claro que a única forma de demonstrar a impontualidade injustificada (sem relevante razão de direito, no dizer da lei) é o protesto do título. Não se admite nenhum 
outro meio de prova - documental, testemunhal ou pericial - para a comprovação do inadimplemento do devedor: apenas o protesto serve a essa finalidade. Sendo assim, qualquer título executivo que o credor possua contra o devedor deve ser levado a protesto, para só depois servir de base ao pedido de falência.

Em contrapartida, sobre a frustação da execução prevista no inciso II do artigo 94, a interpretação sobre a superioridade do crédito a 40 salários mínimos, pode o montante ser composto pela soma de títulos, e não se faz necessário que o credor apresente somente títulos que possuam a integralidade do valor. Assim Coelho (2011) ressalta:

A frustração da execução se caracteriza, por sua vez, com a inexistência de pagamento, depósito ou nomeação de bens à penhora por parte do empresário, quando é ele executado por algum credor (LF, art. 94, II). Nesse caso, a execução deve ser encerrada e o credor, munido de certidão judicial que ateste a verificação da tríplice omissão, ingressa com o pedido de falência contra o devedor. $O$ título, nesse caso, não precisa estar protestado e pode ter valor inferior a 40 salários mínimos.

Visto isso, é importante que sejam observadas todas as regras e ressalvas da lei, para que o procedimento atinja o seu fim por essência, que é, na verdade, possibilitar que os credores tenham adimplidas as suas obrigações, o que pode se fazer até mesmo antes de elas estarem vencidas. Em relação ao tema, explana Ramos (2015):

Ainda sobre o pedido de falência formulado pelo credor do empresário, há uma questão interessante: é necessário que a dívida do devedor em relação a ele esteja vencida? Parecenos que não. A obrigação do devedor em relação ao credor que pede a sua falência não precisa sequer estar vencida. Primeiro, porque o pedido de falência pode estar lastreado na prática de um dos atos de falência previstos no art. 94, III, da LRE, caso em que a demonstração inequívoca de que o devedor incidiu em uma daquelas condutas é por si só suficiente à caracterização de sua insolvência. Segundo, porque, se o devedor já está inadimplente, por exemplo, em relação a outros credores - e não apenas dos que possuem títulos inadimplidos - na instauração da execução concursal. Afinal, se o devedor não está pagando seus credores de hoje, nada garante que ele pagará seus redores de amanhã. Ao contrário, tudo indica que ele não o fará.

Ademais, foram trazidos os casos em que a lei assevera a decretação da falência por iniciativa dos credores, como uma medida utilizada para que possam se valer de meios mais eficazes na cobrança de seus títulos. Entretanto, existe a possibilidade do próprio devedor empresário declarar a sua falência, denominando-se a autofalência.

O instituto da autofalência está previsto no artigo 105 da Legislação supracitada, que inclusive traz como obrigação a declaração empresário que se julgar em crise econômico-financeira. Porém, mesmo com a previsão normativa, é uma prática pouco utilizada dentre os empresários, já que, mesmo prescrevendo a sua necessidade de ocorrência, a lei não prevê penalidades para o seu descumprimento. Em consonância, Ramos (2015) explana:

O pedido de falência feito pelo próprio devedor - chamado de autofalência - apesar de estar previsto em lei, é hipótese raríssima na prática. Na verdade, costuma o devedor em crise tomar duas atitudes, basicamente: (i) não aceitar que sua crise é irremediável, insistindo na atividade até ter, eventualmente, a sua falência decretada a pedido de terceiro, normalmente um credor; ou (ii) encerrar o exercício da atividade empresarial, muitas vezes sem a observância das regras legais impostas para tanto.

Ademais, ressaltadas as diferenças, compreende-se como fundamental para a execução cujo devedor se encontra em estado de insuficiência econômico-financeira que o primeiro passo se dê com a declaração 
da falência. Isso partindo do pressuposto de que a execução esteja fundada sobre um empresário ou uma sociedade empresária. Tratando-se de um empregador não empresário, o processo se consistirá na declaração de insolvência civil.

Em complemento ao tema, inclusive, a Lei Complementar 150, de 2015, denominada lei dos domésticos, além de reconhecer os direitos trabalhistas dos trabalhadores domésticos, também revogou expressamente o inciso I, do art. 3으, da lei 8.009/90, que tratava da impenhorabilidade do bem de família. Tal inovação se constitui em uma ferramenta garantidora da satisfação integral dos créditos trabalhistas, em fase de execução. Assim dispunha o referido inciso revogado:

Art. 3o A impenhorabilidade é oponível em qualquer processo de execução civil, fiscal, previdenciária, trabalhista ou de outra natureza, salvo se movido:

I - Em razão dos créditos de trabalhadores da própria residência e das respectivas contribuições previdenciária. (BRASIL, 1990)

Assim sendo, com o advento da lei, ampliou-se não somente a gama dos direitos trabalhistas dos trabalhadores domésticos, mas houve a regularização da classe, que passou da informalidade para a formalidade. E, ademais, tal inovação possibilitou que a execução ultrapasse tão somente os bens móveis, e estendeu a possibilidade de penhora sobre o domicílio do réu, constituindo uma importante ferramenta garantidora da satisfação do crédito.

\section{A Responsabilidade Subsidiária}

Passadas as considerações acerca da arguição de falência, faz-se fundamental o estudo de outro instituto, o da responsabilidade subsidiária, que se constitui em outra ferramenta, mormente utilizada quando a relação empregatícia se fundamenta em um vínculo indireto com a empresa, ou seja, oriundo da terceirização.

Nesse viés, é importante ressaltar que tal instituto de terceirização possui suas bases no início da modernidade, com uma ótica diversa da que foi se moldando com o passar dos anos. Era uma técnica moderna de gestão, que visava a qualificação das empresas, já que essas atribuiriam atividades-meio a outras empresas com a finalidade de concentrar esforços no desenvolvimento da sua atividade-fim. Nesse sentido, Marcelino et al. (2012):

Em sua quase totalidade, defendia-se a ideia de que as empresas deveriam focar suas 'atividades-fim' e delegar tarefas e processos acessórios ('atividades-meio') a outras empresas especializadas. $\mathrm{O}$ tom fortemente pragmático desse discurso em direção aos benefícios para as empresas tem como pano de fundo uma vaga ideia das noções de modernidade e globalização.

Assim sendo, a terceirização pode ser conceituada como um processo de contratação dos serviços de um trabalhador, que terá vínculo empregatício com outra empresa, ou seja, o vínculo empregatício será com uma empresa, mas a prestação do serviço será para outra empresa.

Sobre o assunto, Marcelino (2007) conceitua: "terceirização é todo processo de contratação de trabalhadores por empresa interposta. Ou seja, é a relação onde o trabalho é realizado para uma empresa, mas contratado de maneira imediata por outra". Percebe-se, portanto, que a apuração depreende que haja 
a contratação por uma empresa, e a execução dos serviços em outra.

Assim conceituada a instituição, é importante reforçar que, caracterizada a relação empregatícia terceirizada, nasce com ela a possibilidade da utilização do instituto da responsabilidade passiva subsidiária. Ou seja, a relação tríade formada entre as partes de uma relação de cunho terceirizado é passível de fundamentar a ação de cobrança do credor trabalhista.

No entanto, para isso, deve restar comprovada, além da inadimplência dos pagamentos, a existência da relação tríade e que a empresa cuja responsabilidade se designar como subsidiária esteja no polo passivo desde a propositura da demanda. Assim, para a extensão da responsabilidade, é necessário que tal entidade seja condenada previamente no processo de conhecimento.

Tal entendimento se conclui a partir da leitura da Súmula 331 do Tribunal Superior do Trabalho, que se constitui na principal fundamentação utilizada para a legalidade da extensão da responsabilização. Tal aparato assim prescreve:

Súmula no 331 do TST: CONTRATO DE PRESTAÇÃO DE SERVIÇOS. LEGALIDADE (nova redação do item IV e inseridos os itens V e VI à redação) - Res. 174/2011, DEJT divulgado em 27, 30 e 31.05.2011

I - A contratação de trabalhadores por empresa interposta é ilegal, formando-se o vínculo diretamente com o tomador dos serviços, salvo no caso de trabalho temporário (Lei no 6.019, de 03.01.1974).

II - A contratação irregular de trabalhador, mediante empresa interposta, não gera vínculo de emprego com os órgãos da Administração Pública direta, indireta ou fundacional (art. 37, II, da CF/1988).

III - Não forma vínculo de emprego com o tomador a contratação de serviços de vigilância (Lei no 7.102, de 20.06.1983) e de conservação e limpeza, bem como a de serviços especializados ligados à atividade-meio do tomador, desde que inexistente a pessoalidade e a subordinação direta.

IV - O inadimplemento das obrigações trabalhistas, por parte do empregador, implica a responsabilidade subsidiária do tomador dos serviços quanto àquelas obrigações, desde que haja participado da relação processual e conste também do título executivo judicial.

V - Os entes integrantes da Administração Pública direta e indireta respondem subsidiariamente, nas mesmas condições do item IV, caso evidenciada a sua conduta culposa no cumprimento das obrigações da Lei no 8.666, de 21.06.1993, especialmente na fiscalização do cumprimento das obrigações contratuais e legais da prestadora de serviço como empregadora. A aludida responsabilidade não decorre de mero inadimplemento das obrigações trabalhistas assumidas pela empresa regularmente contratada.

$\mathrm{VI}$ - A responsabilidade subsidiária do tomador de serviços abrange todas as verbas decorrentes da condenação referentes ao período da prestação laboral.

A partir da leitura dos incisos da referida Súmula, verifica-se de primeiro plano que o instituto da terceirização não é permitido para todas as modalidades de contrato de trabalho, restringindo o seu campo de permissão aos contratos de prestação de serviços de vigilância e de conservação e limpeza, bem como serviços ligados à atividade meio do tomador.

Os requisitos a serem observados para a ocorrência da relação tríade nas relações de trabalho cuja prestação de serviço se enquadre em serviços de segurança e de manutenção e limpeza, conforme estabelece a súmula supracitada, constituem-se na inexistência da pessoalidade e subordinação direta entre o trabalhador e a empresa cujo serviço esteja sendo prestado. 
No entanto, promulgadas as leis 13.429/2017 e 13.467/2017, tal dispositivo foi parcialmente revogado, já que elas alteraram e acrescentaram diversos dispositivos à lei 6.019/74, passando a prever as regras sobre terceirização em nosso país, incluindo a possibilidade de terceirização de atividade-fim.

A Lei 13.467/17 alterou a Lei 6.019/74, intitulada como Lei de Trabalho Temporário, revogando o seu artigo 4ㅇ-A e acrescentando a ele outra redação. Assim, o qualificou como contrato de prestação de serviços e dilatou a sua competência de enquadramento, a fim de possibilitar que sejam terceirizadas também as atividades-fim. Assim dispõe:

Art. 4--A. Considera-se prestação de serviços a terceiros a transferência feita pela contratante da execução de quaisquer de suas atividades, inclusive sua atividade principal, à pessoa jurídica de direito privado prestadora de serviços que possua capacidade econômica compatível com a sua execução.

$\S 1$ 으 A empresa prestadora de serviços contrata, remunera e dirige o trabalho realizado por seus trabalhadores, ou subcontrata outras empresas para realização desses serviços.

$\S 2$ ㅇ Não se configura vínculo empregatício entre os trabalhadores, ou sócios das empresas prestadoras de serviços, qualquer que seja o seu ramo, e a empresa contratante. (BRASIL, 2017)

Ademais, o próprio parágrafo da lei ressalta a não configuração do vínculo de emprego entre a empresa contratante e os trabalhadores ou entre a empresa contratada. Assim sendo, refere a existência da relação tríade formada a partir da assinatura do contrato e consequente cumprimento.

Outrossim, existem duas modalidades de contrato de trabalho previstas em lei que fundamentam a referida relação, sendo elas, o contrato de trabalho temporário ou a contratação de uma empresa para que terceirize as atividades, que constitui o objeto de estudo ora expresso.

A referida responsabilidade foi criada justamente a partir da recorrente situação nos tribunais de para quando empresas que mesmo tendo sido beneficiada pelos serviços prestados pelo empregado da empresa contratada, não era culpada pelos créditos trabalhistas não adimplidos, ainda que comprovados no processo trabalhista, e assim, não eram atingidas pela relação preceituada.

Em seguida, a responsabilidade subsidiária vem preceituada no inciso IV da Súmula 331 do TST, surgindo como ferramenta a ser utilizada naqueles casos em que o credor trabalhista se via prejudicado por não ter estendido ao seu caso o preceito previsto no $\S 20$ do art. 2ㅇ da CLT, que trata da responsabilização solidária entre empresas em relação a créditos trabalhistas.

Nesse sentido, de acordo com o que explana Oliveira (2017), ao contrário da responsabilidade solidária, cuja obrigação aproveita a coparticipação de dois ou mais devedores simultaneamente, a responsabilidade subsidiária utiliza-se de apenas um devedor principal. No entanto, verificada a hipótese do não cumprimento da obrigação por parte deste, a empresa tomadora dos serviços responderá subsidiariamente pela obrigação.

Assim, a referida ferramenta se diferencia da responsabilização solidária, já que, nessa relação existe a responsabilização de ambas as empresas perante a execução do título, já que se verifica a presença da subordinação do trabalhador para ambas concomitantemente. No entanto, naquela, existe a subordinação somente para com a empregadora principal. Tal assunto será mais detalhadamente elucidado a seguir no 
próximo item.

\section{A Responsabilidade Solidária}

Presentes as indagações acerca da responsabilização subsidiária, é de crucial relevância que sejam aclaradas as peculiaridades da responsabilização solidária. Assim, inicialmente, considerando as transformações ocorridas no campo das relações de trabalho, pode-se afirmar que tal responsabilização surgiu para reduzir os índices de inadimplência e trazer maior garantia de efetividade na seara do cumprimento de sentença.

Ademais, primordialmente, a responsabilidade passiva solidária também demanda a regra prevista no parágrafo 5o do artigo 513 do Código de Processo Civil, que assevera que, antes de mais nada, para haver a responsabilização é necessário que o devedor coobrigado seja incluído já no processo de conhecimento. Assim prescreve o artigo:

Art. 513. O cumprimento da sentença será feito segundo as regras deste Título, observandose, no que couber e conforme a natureza da obrigação, o disposto no Livro II da Parte Especial deste Código.

$\S$ 5ㅇ O cumprimento da sentença não poderá ser promovido em face do fiador, do coobrigado ou do corresponsável que não tiver participado da fase de conhecimento. (BRASIL, 2019)

Assim, para o efetivo cumprimento de sentença, o codevedor responsável solidariamente deverá ser parte integrante do processo de conhecimento para que seja respeitado o princípio da ampla defesa e do contraditório, possibilitando que desde já tal devedor possa apresentar defesa, assim como é garantido ao devedor principal.

Ademais, considerando a aplicação de tal instituto ao caso concreto, verifica-se o seu enquadramento nos casos cuja obrigação está fundada em uma relação trabalhista que detenha a presença da figura de um ou mais empregadores, o que poderá caracterizar um grupo econômico ou quando uma empresa está sob a direção, controle ou administração de outra. Sobre o assunto, Silva (2018) elenca:

[...] a figura mais emblemática dessa responsabilização seja o instituto do grupo econômico. Por isso mesmo, desde 1943, a CLT contém regra específica dimensionando a responsabilidade solidária das empresas integrantes de grupo econômico pelo adimplemento das verbas trabalhistas sonegadas durante o curso da relação de emprego. Segundo a regra originária do $\S 2$ ] do art. 2[] da CLT, ainda que a empresa tenha personalidade jurídica própria e não seja a empregadora, sempre que estiver sob a direção, controle ou administração de outra - integrando ambas um grupo econômico - será com esta responsável solidária pelas obrigações trabalhistas.

Previamente, quanto às alterações trazidas pela reforma trabalhista, tal entendimento se manteve o mesmo consolidado na antiga lei trabalhista, no sentido de resguardar o reconhecimento por hierarquia. Constitui, assim, tema de muitas dúvidas e oposição, já que a doutrina e a jurisprudência mantêm o entendimento de que deve prevalecer o reconhecimento horizontal.

No mesmo sentido, também guarda a jurisprudência o entendimento de que tal constituição deve ser facilitada, não devendo caber nem mesmo a regra prescrita no artigo 513 do Código de Processo Civil, que trata da inclusão ao polo passivo a empresa coobrigada já no processo de conhecimento. Assim explana 
Schiavi (2018):

O objetivo da lei foi tornar mais difícil a configuração do grupo econômico para fins de responsabilização trabalhista. Não obstante, a jurisprudência já se posicionou no sentido de que é possível a responsabilização, na execução, da empresa do grupo econômico que não participou da fase de conhecimento.

Ademais, quanto ao usufrutuário de tal ferramenta, cumpre destacar que ela poderá ser utilizada por ambos os sujeitos processuais. Assim, tanto o empregado quanto alguma das empresas compreendidas entre um dos codevedores responsáveis. Assim, em relação ao tema, Süssekind (1994) explana:

Reconhecida que a solidariedade é ativa e passiva, certo é que, tanto o empregado poderá agir judicialmente, em relação ao seu contrato de trabalho, contra qualquer das sociedades componentes do grupo, como este poderá exercer os direitos de empregador no concernente aos seus empregados. Mas esses direitos - convém sublinhar - estão sujeitos a diversas limitações legais, convencionais ou contratuais: tal como dentro de uma empresa, ao grupo empregador não será lícito alterar, livremente, as condições de trabalho.

Ademais, cumpre destacar o que assevera a Súmula 129 do Tribunal Superior do Trabalho, que fortalece o entendimento pela responsabilidade solidária sem que haja de fato o vínculo trabalhista formalizado com ambos empregadores. Nesses termos, assim elenca:

Súmula no 129 do TST - CONTRATO DE TRABALHO. GRUPO ECONÔMICO (mantida) - Res. $121 / 2003$, DJ 19, 20 e 21.11 .2003

A prestação de serviços a mais de uma empresa do mesmo grupo econômico, durante a mesma jornada de trabalho, não caracteriza a coexistência de mais de um contrato de trabalho, salvo ajuste em contrário.

De acordo com o tema, Moura (2018) destaca que a atual lei trabalhista trouxe outra significativa mudança, a dispensa de que haja, para a configuração do grupo econômico urbano, a existência de uma empresa controladora. Assim, não está dispensado o controle de uma empresa por outra, apenas que já não mais se faz necessário a constituição de uma empresa especificamente destinada a controlar as demais.

Nesse sentido, de acordo como artigo 264 do Código Civil é possível afirmar que se configura a solidariedade nos casos em que participam na mesma obrigação mais de um credor, ou mais de um devedor, estando cada um com direito, ou obrigado, à dívida toda. No entanto, no Direito do Trabalho o entendimento se vê controverso.

A contrariedade se encontra a respeito da tipificação da solidariedade, se recai exclusivamente sobre o polo passivo ou, se supletivamente aplica-se o dispositivo do Código Civil e se estende ao polo ativo. Sobre o tema, Meirelles (2002) explana:

[...] transportando essas lições para a relação de emprego mantida com o grupo econômico, ter-se-ia que passiva é a solidariedade das empresas agrupadas pelos débitos constituídos pelo empregador frente ao trabalhador. Aqui teríamos mais de um devedor (as empresas agrupadas) "obrigado a dívida toda". Ativa, por sua vez, seria a solidariedade das empresas agrupadas frente ao empregado pelas obrigações assumidas por este em decorrência do contrato de emprego. Neste caso, o empregado seria devedor frente as empresas agrupadas (especialmente pela obrigação de prestar serviços). Por via de consequência, diante dessa hipótese, "cada um dos credores solidários tem direito a exigir do devedor o cumprimento da prestação, por inteiro".

Nesse diapasão, constata-se a suma importância evidenciada na expressão destacada, já que tal instituto se fundamenta como constituidor de mais uma ferramenta a ser utilizada na busca pela efetivação e consolidação dos direitos trabalhistas. A próxima ferramenta a ser elencada trata-se da desconsideração 
da personalidade jurídica.

\section{A Desconsideração da Personalidade Jurídica}

Antes de adentrar ao tema, se faz imprescindível a conceituação de alguns pontos introdutórios. Assim sendo, iniciando, visa-se demonstrar não somente o conceito de personalidade jurídica, como o conceito de empresário.

De acordo com Diniz (2014) "a pessoa jurídica é a unidade de pessoas naturais ou de patrimônios, que visa à consecução de certos fins, reconhecida pela ordem jurídica como sujeito de direitos e obrigações".

Assim, havendo uma pessoa ou pluralidade de pessoas, detentoras de bens a serem destinados a uma atividade econômica organizada com fins lucrativos, explorando a atividade econômica, e que é reconhecida juridicamente, pois observou os requisitos de existência previstos em lei. Sobre a constituição da personalidade jurídica, o artigo 45 do Código Civil de 2002 deixa clara a conceituação:

Começa a existência legal das pessoas jurídicas de direito privado com a inscrição do ato constitutivo no respectivo registro, precedida, quando necessário, de autorização ou aprovação do Poder Executivo, averbando-se no registro todas as alterações por que passar o ato constitutivo.

Nesse diapasão, é importante que seja observado o referido registro, que será instituído mediante o requerimento de empresário, quando se tratar de um empresário individual, ou assinatura do contrato social, quando se tratar de uma sociedade empresária. Estes documentos indicarão as informações pertinentes à empresa e obedecem às regras trazidas no artigo 968 do Código Civil de 2002, quais sejam:

Art. 968. A inscrição do empresário far-se-á mediante requerimento que contenha:

I - O seu nome, nacionalidade, domicílio, estado civil e, se casado, o regime de bens;

II - A firma, com a respectiva assinatura autografa que poderá ser substituída pela assinatura autenticada com certificação digital ou meio equivalente que comprove a sua autenticidade, ressalvado o disposto no inciso I do § 10 do art. 4o da Lei Complementar no 123, de 14 de dezembro de 2006;

III - O capital;

IV - O objeto e a sede da empresa.

$\S 10$ Com as indicações estabelecidas neste artigo, a inscrição será tomada por termo no livro próprio do Registro Público de Empresas Mercantis, e obedecerá a número de ordem contínuo para todos os empresários inscritos.

$\S 20$ À margem da inscrição, e com as mesmas formalidades, serão averbadas quaisquer modificações nela ocorrentes.

Assim sendo, sobre o caráter de empresa, para melhor se obedecer às regras contidas no artigo supracitado, é importante que se tenha a definição correta sobre a instituição, tendo em mente as diferenças cruciais existentes entra empresário individual e sociedade empresária. Sobre o tema, assim conceitua Ramos (2015):

O art. 966 do Código Civil, ao conceituar empresário como aquele que exerce profissionalmente atividade econômica organizada, não está se referindo apenas à pessoa física (ou pessoa natural) que explora atividade econômica, mas também à pessoa jurídica. Portanto, temos que o empresário pode ser um empresário individual (pessoa física que exerce profissionalmente atividade econômica organizada) ou uma sociedade empresária (pessoa jurídica constituída sob a forma de sociedade cujo objeto social é a exploração de uma atividade econômica organizada). 
Nesse ponto, em consonância com o que elenca Tartuce (2018) é logo após a sua devida constituição que é atribuído à pessoa jurídica uma gama de direitos, tais como relacionados à personalidade, obrigacionais, direitos industriais quanto a marcas e nomes e direitos sucessórios.

Outro ponto essencial a ser destacado é que a pessoa jurídica possui existência independente dos seus sócios, ou seja, a ela é atribuída uma personalidade própria. Portanto, é em razão dessa personalidade que se torna possível que ela seja detentora de direitos e deveres, tal como explicitado acima.

Outrossim, é essa personalidade o fator determinante para que não sejam confundidos os bens dos sócios com os da empresa. Ou seja, isso quer dizer que a empresa possui bens próprios que responderão pelas suas obrigações, sem que sejam confundidos os bens dos seus sócios.

No entanto, tal regra poderá ser afastada, e tornar possível a desconsideração da personalidade jurídica, nos casos em que houver alguma violação de alguns de seus princípios e fins, lesionando a terceiros. Assim explicita Tartuce (2018):

Mas tal regra pode ser afastada, nos casos de desvio de finalidade ou abuso da personalidade jurídica, situações em que merece aplicação o art. 50 do CC, que trata da desconsideração da personalidade jurídica. De imediato, pode-se afirmar que a desconsideração da personalidade jurídica nada mais é do que a desconsideração daquela antiga regra pela qual a pessoa jurídica não se confunde com os seus membros.

Nesse diapasão, a desconsideração da personalidade jurídica é uma importante ferramenta a ser utilizada pelo trabalhador na cobrança de seus créditos. É a partir dela que ao credor trabalhista é incumbida a possibilidade de buscar de forma mais eficaz a satisfação de seu crédito, além de desmascarar eventuais falcatruas oriundas do gerenciamento dos sócios administradores. Sobre o tema, Tartuce (2018) explana:

Tal instituto permite ao juiz não mais considerar os efeitos da personificação da sociedade para atingir e vincular responsabilidades dos sócios, com intuito de impedir a consumação de fraudes e abusos por eles cometidos, desde que causem prejuízos e danos a terceiros, principalmente a credores da empresa. Dessa forma, bens particulares dos sócios podem respondem pelos danos causados a terceiros.

Portanto, levando em consideração o que foi dito acima, é importante ressaltar que o referido instituto é, na verdade, uma ferramenta que possibilita, excepcionalmente, a retirada da autonomia atribuída à sociedade, para que se torne possível chegar aos bens dos sócios. Mas ressalta-se, é medida excepcional, que sozinha não gera a desconstituição da sociedade. Nas palavras de Tomazette (2014):

\footnotetext{
A desconsideração é, pois, a forma de adequar a pessoa jurídica aos fins para os quais ela foi criada, vale dizer, é a forma de limitar e coibir o uso indevido deste privilégio que é a pessoa jurídica, uma forma de reconhecer a relatividade da personalidade jurídica das sociedades. Este privilégio só se justifica quando a pessoa jurídica é usada adequadamente, o desvio da função faz com que deixe de existir razão para a separação patrimonial. O conceito será sustentado apenas enquanto seja invocado e empregado para propósitos legítimos. A perversão do conceito para usos impróprios e fins desonestos (e.g., para perpetuar fraudes, burlar a lei, para escapar de obrigações), por outro lado, não será tolerada. Entre esses são várias as situações onde as cortes podem desconsiderar a pessoa jurídica para atingir um justo resultado.
}

Não é de hoje que a ferramenta é reconhecida no ordenamento jurídico. No entanto, é recente a alteração legislativa que trouxe para a lei trabalhista a possibilidade de valer-se do instituto como ferramenta processual. A alteração veio com a inserção do artigo 855-A da Consolidação das Leis do Trabalho. Sobre o assunto, assim elenca Schiavi (2018): 
O artigo 855-A, da CLT, determina a aplicação do incidente de desconsideração ao processo do trabalho, previsto no CPC, com as seguintes adaptações:

a) da decisão interlocutória que acolher ou rejeitar o incidente;

b) na fase de cognição, não cabe recurso de imediato, na forma do § 10 do art. 893 desta Consolidação;

c) na fase de execução, cabe agravo de petição, independentemente de garantia do juízo;

d) cabe agravo interno se proferida pelo relator em incidente instaurado originariamente no tribunal.

e) a instauração do incidente suspenderá o processo, sem prejuízo de concessão da tutela de urgência de natureza cautelar de que trata o art. 301 da Lei n. 13.105, de 16 de março de 2015 (Código de Processo Civil).

Assim, destaca-se que o artigo veio para efetivar a prática que já vinha acontecendo naqueles casos em que não é possível localizar bens em nome da empresa empregadora, estendendo-se a busca aos bens dos sócios. O referido artigo ainda mantém a referência ao Código de Processo Civil, mas especificamente aos artigos em que está expresso o instituto.

Entretanto, diferentemente do processo civil, foram acrescentadas algumas ressalvas para que melhor se adequasse ao processo trabalhista. Uma delas se refere à impossibilidade de recurso, se pleiteado o incidente na fase de cognição, permitindo, entretanto, o agravo de petição se pleiteado em fase de execução e agravo interno se proferida pelo relator em incidente instaurado pelo tribunal.

Ainda, refere o parágrafo segundo do artigo a ocorrência da suspensão do processo, asseguradas as medidas cautelares previstas no artigo 301 do CPC. Porém, em relação ao procedimento que era resguardado pela Instrução Normativa n.39/16, a grande inovação foi a retirada da possibilidade do Juiz do Trabalho tomar a iniciativa de instaurar o incidente.

Visto isso, para melhor compreender o incidente, importante referenciar os artigos do CPC que embasam a aplicação e trazem a procedimentalização do instituto. Tais artigos correspondem aos artigos 133 a 137 do referido Código. Em relação à análise da aplicação das regras explicitadas nos artigos do CPC, assim explana Schiavi (2018):

Em favor da aplicação deste incidente ao processo do trabalho, destacam-se:

a) a omissão da legislação processual trabalhista quanto à questão;

b) a Justiça do Trabalho utiliza as regras de direito material previstas no Código de Defesa do Consumidor e no Código Civil para fundamentar a desconsideração da personalidade jurídica, tanto direta quanto inversa;

c) a observância do devido processo legal, oportunizando o contraditório prévio antes de invadir a esfera patrimonial do sócio, ou da pessoa jurídica (teoria inversa);

d) a justiça e o equilíbrio do procedimento.

Portanto, afirma-se a omissão da legislação trabalhista sobre a instauração do incidente, sendo, no entanto, destacadas breves ressalvas no caput do artigo. Ainda, quanto à caracterização do instituto, percebe-se consubstanciado nas regras do artigo 50 do Código Civil e do artigo 28, caput e §5으 do Código de Defesa do Consumidor.

Assim, as menções legais trazem diferenças, tais são elas que a doutrina as dividiu em duas principais que servem de embasamento à afirmação do instituto. Para uma melhor conceituação e diferenciação, 
importante se faz a referência de Tartuce (2018):

a) Teoria maior - a desconsideração, para ser deferida, exige a presença de dois requisitos: o abuso da personalidade jurídica + o prejuízo ao credor. Essa teoria foi adotada pelo art. 50 do CC/2002.

b) Teoria menor - a desconsideração da personalidade jurídica exige um único elemento, qual seja o prejuízo do credor. Essa teoria foi adotada pela Lei 9.605/1998 - para os danos ambientais - e, supostamente, pelo art. 28 do Código de Defesa do Consumidor.

Nesse sentido, a teoria maior expressa no artigo 50 do Código Civil, elenca a presença de dois requisitos, oferecendo maior dificuldade para a desconsideração. O abuso da personalidade jurídica representa a utilização da figura da empresa para fins diversos àqueles que justificam o seu surgimento. Sobre o tema, assim explana Redondo (2012):

A confusão patrimonial se dá "quando os sócios, administradores ou associados utilizam, em proveito próprio, os bens e recursos da pessoa jurídica, em verdadeira 'promiscuidade' entre os bens da sociedade e os de seus representantes. Exemplos comuns de confusão patrimonial extraídos da prática forense são os casos em que a sociedade paga dívidas do sócio, ou este recebe créditos dela, ou o inverso, revelando a inexistência de distinção, no plano patrimonial, entre essas pessoas (o que pode ser verificado, v.g., por meio da escrituração contábil ou da movimentação de contas de depósito bancário), ou então quando bens de sócios estão registrados em nome da sociedade, ou vice-versa".

Assim, tal abuso representa um desvio da finalidade, a confusão patrimonial ocorrida quando os sócios da empresa utilizam da sua personalidade para mascarar falcatruas e dispersar credores. Aqui já se engloba o segundo requisito, o prejuízo ao credor, já que geralmente tais condutas se constituem a fim de atribuir proveito pessoal em cima de condutas prejudiciais a terceiros, que muitas vezes descobrem somente ao final que foram vítimas.

Sobre a teoria menor expressa no Código de Defesa do Consumidor, basta que se verifique o prejuízo do credor, que pode, também, ser evidenciada pelo abuso de direito, infração decorrente de ato ou fato ilícito, insolvência, entre outros. Sobre o assunto, assim destaca Tamer (2016):

Nas relações de consumo, diferentemente, os pressupostos legais para desconsideração são aqueles previstos no art. 28 do Código de Defesa do Consumidor, segundo o qual a pessoa jurídica pode ser tida por inexistente no caso em concreto se, em detrimento do consumidor, se "houver abuso de direito, excesso de poder, infração da lei, fato ou ato ilícito ou violação dos estatutos ou contrato social" ou ainda "quando houver falência, estado de insolvência, encerramento ou inatividade da pessoa jurídica provocados por má administração".

Nesse sentido, o leque em relação às possibilidades é aumentado, já que se faz necessário apenas um requisito. Basta que esteja verificado o prejuízo ao credor, que nesse caso se trata do consumidor, ou que se perceba alguma articulação por parte da empresa para impedir a execução para que reste configurada a possibilidade da desconsideração.

Outrossim, destacadas as diferenças existentes dentre as fundamentações existentes para as teorias, destaca-se, ainda, a existência da teoria inversa. Tal teoria possibilita a desconsideração inversa da personalidade, ou seja, as dívidas passam a ser endereçadas à empresa, e não mais a algum dos sócios. Sobre o tema, assim elenca Gonçalves (2018):

Além da desconsideração comum, há ainda a inversa. Na comum, a responsabilidade patrimonial pelas dívidas da empresa é estendida aos sócios; na inversa, a responsabilidade pelas dívidas dos sócios é estendida à empresa. No primeiro caso, embora a dívida seja da 
pessoa jurídica, o sócio passa a responder judicialmente pelo débito com seu patrimônio pessoal; no segundo, conquanto o débito seja do sócio, será possível alcançar bens da empresa, a quem a responsabilidade é estendida. [...] Assim, haverá necessidade de instauração do incidente quando, por exemplo, se queira atingir o patrimônio de empresa controladora por negócios jurídicos realizados por empresas coligadas, que funcionam como uma espécie de longa manus daquelas; ou para estender a responsabilidade patrimonial a sócios ocultos, que se valem de sócios aparentes (os chamados "laranjas") para fugir da responsabilidade.

Assim, anteriormente à reforma, foram muito aplicadas as teorias nos processos trabalhistas, trazendo para o polo ativo o trabalhador, que analogicamente ocupava a posição do consumidor ou do credor civilista. No entanto, a partir da evolução normativa a própria reforma trabalhista trouxe a possibilidade em lei, para que seja devidamente fundamentada a execução.

Nesse diapasão, percebe-se que, mesmo que a alteração tenha sido alvo de muitas críticas por parte da doutrina, ela nada mais fez do que consolidar em um artigo de lei uma prática que já era recorrente e que se constitui como ferramenta ao trabalhador, quando encontra dificuldade em receber os valores e créditos que representam o seu direito.

Ademais, ressalta-se que a implementação do artigo com as devidas ressalvas e adequações, devido à necessidade da aplicação em muitas lides processuais cuja finalidade da ação judicial se vê prejudicada, trouxe nada mais do que a consolidação necessária. E, ainda, naquilo que restar dúvidas, ou permanecer a legislação omissa, segue-se tendo como parâmetro as doutrinas civilistas e consumeristas.

Assim, o próprio doutrinador Schiavi (2018) ressalta que, na verdade, o referido artigo trouxe em sua previsão praticamente uma réplica da IN 39/16, que se constituía no instrumento utilizado para a regulamentação do instituto da desconsideração também no âmbito trabalhista. Constitui, assim, um reforço para a aplicação, e a consequente efetivação do instituto.

Ademais, tais atributos constituem forte embasamento para que de fato reste efetivada a tutela jurisdicional e para que esteja assegurado ao trabalhador a efetividade do processo. Tal crédito consiste em pressuposto fundamental para a sua subsistência, no momento em que o deixa de receber, grandes serão os reflexos na sua vida cotidiana.

O mais importante aqui é ressaltar tamanha importância, a fim de que se justifique tal especificidade da causa e, encontrando maiores dificuldades para o recebimento de seu crédito, seja garantido ao trabalhador as prerrogativas constitucionais para que ele possa se valer das possibilidades descritas nesse trabalho.

Justifica-se, desse modo, a afirmação de que nem sempre os institutos previstos em lei, abordados neste trabalho, são suficientemente capazes de garantir um processo de execução célere, eficaz, e que atinja o objeto principal ensejado desde a peça exordial. Ao mesmo tempo, nesses casos, haverá a necessidade de desbravar todos os institutos, aplicando-os ao caso concreto quando pertinentes.

\section{CONCLUSÕES}

A proteção ao trabalhador se percebe cada vez mais emergente, tendo em vista que é de crucial relevância que a ele se perceba atendido o convencionado. Uma vez estabelecida essas trocas, com ônus e 
benesses para ambas as partes, devem ser cumpridas e respeitadas as normas preestabelecidas.

Para tanto, deve ser levado em consideração que a eficácia da execução está atrelada, muitas vezes, à coerção imposta em face do executado, já que a penalidade imposta traz consequências drásticas, como no caso do devedor de alimentos, cuja penalidade extrapola os limites do patrimônio e acarreta prisão civil. O devedor se obriga a pagar em virtude da sanção que lhe é imposta, ela opera como fator de eficaz persuasão.

Em situações semelhantes à descrita acima, nos casos em que o credor de créditos trabalhistas se vê prejudicado, a Consolidação das Leis do Trabalho prevê alguns mecanismos possíveis para impedir novos acontecimentos, tais como, a arguição de falência, a responsabilidade subsidiária, a solidária e a desconsideração da personalidade jurídica.

Assim sendo, objetivou-se aqui, a partir de uma explanação sucinta dessas modalidades cabíveis para a satisfação dos créditos trabalhistas, a demonstração dos caminhos e trilhas possíveis ao trabalhador que percebe as suas obrigações não satisfeitas e verifica a inexistência de bens passíveis de nomeação à penhora. Tais ferramentas, entretanto, se demonstram contributivas para o alcance da finalidade que lhes é imposta, que nem sempre é alcançada por não se constituírem tais meios como eficazes em si mesmos. Isso porque, em alguns casos, Ihes carece de poder coercitivo.

Visto isso, em muitos desses casos em que a tutela jurídica não resta devidamente resguardada, o resultado almejado desde a propositura da demanda que não se consuma, acarreta a violação da tutela constitucional inerente aos direitos individuais e sociais. Assim, a inexequibilidade daquele título originado da demanda ou da via extrajudicial, culmina na ineficácia da persecução processual.

Nessa seara, denota-se a título conclusivo que houvera indagado aqui o estudo dos institutos processuais cabíveis, cabendo, em um próximo momento, o estudo mais aprofundado acerca da eficácia desses institutos perante os tribunais. Cabe, ainda, a análise da ordem em que se perfaz a sua aplicação, para que se possa, a partir disso, aprimorar esses institutos consonantemente à complexidade da causa.

\section{REFERÊNCIAS}

BRASIL. Código Civil: lei n. 10.406, de 10 de janeiro de 2002. Brasília: DOU, 2002.

BRASIL. Código de Processo Civil: lei n. 13.105, de 16 de março de 2015. Brasília: DOU, 2015.

BRASIL. Súmulas do Tribunal Superior do Trabalho: Súmula no 301 do TST. Brasília: DOU, 2003.

BRASIL. Lei n. 13.467, de 13 de julho de 2017. Brasília: DOU, 2017.

BRASIL. Lei n. 8.009, de 1990. Brasília: DOU, 1990.

BRASIL. Lei n. 11.101, de 9 de fevereiro de 2005. Brasília: DOU, 2005.

BRASIL. Lei Complementar n. 150 de 2015. Brasília: DOU, 2015.
COELHO, F. U.. Manual de direito comercial: direito de empresa. 23 ed. São Paulo: Saraiva, 2011.

DINIZ, M. H.. Curso de direito civil brasileiro, volume I: teoria geral do direito civil. 31 ed. São Paulo: Saraiva, 2014.

GOMES, F. V.. A insolvência civil. Revista Direitonet, 2013.

GONÇALVES, M. V. R.. Direito processual civil

esquematizado. São Paulo: Saraiva Educação, 2018.

MARCELINO, P.. Afinal, o que é terceirização? Em busca de ferramentas de análise e de ação política. Pegada: A Revista da Geografia do Trabalho, v.8, n.2, 2007.

MARCELINO, P.; CAVALCANTE, S.. Por uma definição de terceirização. Revista Caderno CRH, Salvador, v.25, n.65, p.331-346, 2012. 
MEIRELLES, E.. Grupo Econômico Trabalhista. São Paulo: LTr, 2002.

MOURA, M.. Reforma trabalhista: comentários à Lei 13.467/2017, artigo por artigo. JusPODIVM 2018.

OLIVEIRA, J. S.. Responsabilidade solidária e subsidiária das empresas, grupo econômico e sucessão de empregadores. Jusbrasil, 2017.

RAMOS, A. L. S. C.. Direito Empresarial Esquematizado. 5 ed. São Paulo: Método, 2015.

REDONDO, B. G.. Desconsideração da personalidade jurídica: aspectos materiais e processuais civis. In: VENOSA, S.. 10 anos do Código Civil desafios e perspectivas. São Paulo: Atlas, 2012
SCHIAVI, M.. A reforma trabalhista e o processo do trabalho. São Paulo: LTr, 2018.

SILVA, J.. Lei n. 13.467, de 13 de julho de 2017. Comentários à lei da reforma trabalhista: dogmática, visão crítica e interpretação constitucional. São Paulo: LTr, 2018.

SÜSSEKIND, A.. Grupo Empregador. Revista TST, Brasília, n.63, p.66-74, 1994.

TAMER, M. A.. O perfil da desconsideração da personalidade jurídica no código de processo civil de 2015. Revista dos Tribunais, v.112, n.424, p.255-271, 2016.

TARTUCE, F.. Manual de direito civil, volume único. 8 ed. Rio de Janeiro: Forense; São Paulo: Método, 2018.

TOMAZETTE, M.. Curso de direito empresarial: teoria geral e direito societário, volume 1. 6 ed. São Paulo: Atlas, 2014.

A CBPC - Companhia Brasileira de Produção Científica (CNPJ: 11.221.422/0001-03) detém os direitos materiais desta publicação. Os direitos referem-se à publicação do trabalho em qualquer parte do mundo, incluindo os direitos às renovações, expansões e disseminações da contribuição, bem como outros direitos subsidiários. Todos os trabalhos publicados eletronicamente poderão posteriormente ser publicados em coletâneas impressas sob coordenação da Sustenere Publishing, da Companhia Brasileira de Produção Científica e seus parceiros autorizados. Os (as) autores (as) preservam os direitos autorais, mas não têm permissão para a publicação da contribuição em outro meio, impresso ou digital, em português ou em tradução. 